ISSN 2674-8169

\title{
HKUMed finds Omicron SARS-CoV-2 can infect faster and better than Delta in human bronchus but with less severe infection in lung. \\ MC Chan
}

\section{SHORT COMMUNICATION ARTICLE}

Abstract

A study led by researchers from the LKS Faculty of Medicine at The University of Hong Kong (HKUMed) provides the first information on how the novel Variant of Concern (VOC) of SARS-CoV2 , the Omicron SARS-CoV-2 infect human respiratory tract. The researchers found that Omicron SARS-CoV-2 infects and multiplies 70 times faster than the Delta variant and original SARS-CoV-2 in human bronchus, which may explain why Omicron may transmit faster between humans than previous variants. Their study also showed that the Omicron infection in the lung is significantly lower than the original SARS-COV-2, which may be an indicator of lower disease severity. This research is currently under peer review for publication.

Key words: SARS-CoV-2, Omicron, COVID-19 


\section{SHORT IMPLANTS}

\section{Resumo}

Um estudo liderado por pesquisadores da Faculdade de Medicina LKS da Universidade de Hong Kong (HKUMed) fornece as primeiras informações sobre como o novo Variant of Concern (VOC) do SARS-CoV-2, o Omicron SARS-CoV-2 infecta humanos trato respiratório. Os pesquisadores descobriram que o Omicron SARS-CoV-2 infecta e se multiplica 70 vezes mais rápido que a variante Delta e o SARS-CoV-2 original no brônquio humano, o que pode explicar por que o Omicron pode transmitir mais rapidamente entre humanos do que as variantes anteriores. Seu estudo também mostrou que a infecção por Omicron no pulmão é significativamente menor que o SARS-CoV-2 original, o que pode ser um indicador de menor gravidade da doença. Esta pesquisa está atualmente sob revisão por pares para publicação.

Palavras Chave: SARS-CoV-2, Omicron, COVID-19

Instituição afiliada: LKS Faculty of Medicine at The University of Hong Kong (HKUMed)

Dados da publicação: Artigo recebido em 20 de Outubro, revisado em 15 de Novembro, aceito para publicação em 10 de Dezembro e publicado em 31 de Janeiro de 2022

DOI: https://doi.org/10.36557/2674-8169.2022v4n1p50-54

Autor correspondente: MC Chan medfac@hku.hk

Este artigo é uma cópia da materia vinculada ao site https://www.med.hku.hk/en/news/press/20211215omicron-sars-cov-2-infection . Este artigo não foi submetido por MC Chan.

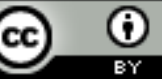

This work is licensed under a Creative Commons Attribution 4.0 International

License. 


\section{Research findings}

Dr Michael Chan Chi-wai, Associate Professor of School of Public Health and Principal Investigator, Centre for Immunology and Infection (C2i), Hong Kong Science and Technology Park (HKSTP) and Professor John Nicholls, Professor of Department of Pathology, HKUMed have pioneered the use of ex vivo cultures of the respiratory tract for investigating many emerging virus infections since 2007, such as avian influenza, coronavirus of the Middle East Respiratory Syndrome (MERS). Now this technique has been applied to understand why the Omicron variant may differ in transmission and disease severity from other SARS-CoV-2 variants.

This method uses lung tissue removed for treatment of the lung, which is normally discarded, for investigating virus diseases of the respiratory tract. Dr Chan and his team successfully isolated the Omicron SARS-CoV-2 variant and used this experimental model to compare infection with the original SARS-CoV-2 from 2020, the Delta variant and the recent Omicron variant. They found that the novel Omicron variant replicates faster than the original SARS-CoV-2 virus and Delta variant in the human bronchus. At 24 hours after infection, the Omicron variant replicated around 70 times higher than the Delta variant and the original SARS-CoV-2 virus. In contrast, the Omicron variant replicated less efficiently (more than 10 times lower) in the human lung tissue than the original SARS-CoV-2 virus, which may suggest lower severity of disease.

'It is important to note that the severity of disease in humans is not determined only by virus replication but also by the host immune response to the infection, which may lead to dysregulation of the innate immune system, i.e. "cytokine storm",' said Dr Chan. 'It is also noted that, by infecting many more people, a very infectious virus may cause more severe disease and death even though the virus itself may be less pathogenic. Therefore, taken together with our recent studies showing that the Omicron variant can partially escape immunity from vaccines and past infection, the overall threat from Omicron variant is likely to be very significant.'

\section{About the research team}

The research was conducted by a team led by Dr Michael Chan Chi-wai, Associate Professor, School of Public Health, HKUMed and Principal Investigator, C2i, HKSTP. The research team included Dr Kenrie Hui Pui-yan, Assistant Professor; Professor Malik Peiris, Tam Wah-Ching Professor in Medical Science and Chair Professor of Virology, Professor Leo Poon Lit-man, School of Public Health, HKUMed; and Professor John Nicholls, Clinical Professor, Department of Pathology, HKUMed. 


\section{Acknowledgements}

This research was supported by grants from the National Institute of Allergy and Infectious Diseases (contract HHSN272201400006C), Research Grant Council (T11-712/19-N) and the Health and Medical Research Fund (COVID190202), Government of the Hong Kong Special Administrative Region.

Special thanks to Department of Cardiothoracic Surgery, Queen Mary Hospital.

\section{About the School of Public Health, HKUMed}

The School of Public Health, LKS Faculty of Medicine of the University of Hong Kong has a long and distinguished history in public health education and high impact research. With world leading research in infectious diseases as well as on non-communicable diseases of both local and global importance, the School has made significant contributions through its research and advocacy to improve the health of populations and individuals, both locally and globally. The School is a leading research and teaching hub in public health on influenza and other emerging viruses, control of non-communicable and infectious diseases, tobacco control, air pollution, psycho-oncology, behavioral sciences, exercise science, life-course epidemiology, and health economics, health services planning and management.

\section{Media enquiries}

Please contact LKS Faculty of Medicine of The University of Hong Kong by email (medmedia@hku.hk).

\section{REFERÊNCIAS}

1- LKS Faculty of Medicine of The University of Hong Kong https://www.med.hku.hk/en/news/press/20211215-omicron-sars-cov-2-infection

2- Chan MC. HKUMed finds Omicron SARS-CoV-2 can infect faster and better than Delta in human bronchus but with less severe infection in lung. 